\title{
DIMENSI SPIRITUAL MANUSIA
}

\author{
Mida Purba \\ midapurba@yahoo.com \\ STKIP Widya Yuwana
}

\begin{abstract}
This article wants to explorethe fact that human being has spiritual dimension which is not contradict to his or her body. This article will point out that spiritual dimension of human being by using the expereince of St. Vincent de Paul and at the same time showing that human expereince as a locus of God's revealing self-disclousure. God's revealing self-disclousure is very much interconnected with the notion of God as Divine Providende because through God's selfdisclousure, He brings meaning to the life of His people. This takes place in ordinary daily life. It is the spirit of human being enable them from time to time to related them selves to higher reality, God.The writer uses hermeneutic approach to analyze topic of discussion.
\end{abstract}

Keywords: spirit, daily life, revelation, human nature.

\section{PENDAHULUAN}

Manusia sering jatuh pada pemenuhan aspek material saja. Hal itu barangkali terjadi karena kurang menyadari dengan baik bahwa kebutuhan manusia tidak hanya terletak pada pemenuhan kebutuhan material, yang pada kenyataanya harus dipenuhi. Paus Fransiskus melalui seruan apostoliknya 2013 dalam dokumen Evangelii Gaudium, mengungkapkan masalah ini. Beliau mengingatkan dunia kita yang ditandai oleh sifat konsumtif yang membuat hati nurani manusia tumpul. Batin terbelenggu oleh kepentingan sendiri saja dan kurang membuka ruang bagi yang lain dengan segala akibat buruknya. Artikel ini dimaksudkan memberikan salah satu alternatif untuk mengatasi masalah tersebut. Terutama memberikan sumbangan pemikiran terhadap pendidikan dan pembentukan karakter dari calon guru agama Katolik dan katekis di STKIP Widya Yuwana.

\section{PEMBAHASAN}

“Adakah kapak memegahkan diri terhadap orang yang memakainya, atau gergaji membesarkan diri terhadap orang yang mempergunakannya? Seolah-olah gada menggerakkan orang yang mengangkatnya dan seolah-olah tongkat mengangkat orangnya yang bukan kayu!” (Yes 10: 15). Demikian Nabi Yesaya 
menggambarkan relasi manusia dengan Allah. Yesaya memperlihatkan, walau manusia mampu melakukan sesuatu karena potensi yang dimilikinya, dia bukanlah satu-satunya yang menentukan aksinya. Dia adalah orang yang dituntun oleh pemiliknya sesuai dengan kapasitas unik yang dimilikinya. Karena itu, patutlah bila manusia mempunyai sikap yang tepat, rendah hati dihadapan Allah.

Kitab Kejadian menjelaskan manusia adalah gambar Allah. "Allah menciptakan manusia itu menurut gambarNya, menurut gambar Allah diciptakanNya dia; lakilaki dan perempuan diciptakanNya mereka” ( Kej 1: 27). Kesadaran akan identitas manusia sebagai anak Allah, yang diciptakan oleh-Nya menurut gambar-Nya, sering luput. Akibatnya adalah suara Allah tak lagi didengar dan suka-cita kasihNya tak lagi dirasakan. Hal itulah yang disampaikan oleh Paus Fransiskus dalam Evangelii Gaudium, seruan apostoliknya 2013 yang lalu.

Bahaya besar dalam dunia sekarang ini, yang diliputi konsumerisme, adalah kesedihan dan kecemasan yang lahir dari hati yang puas diri namum tamak, pengejaran akan kesenangan sembrono dan hati nurani yang tumpul. Ketika kehidupan batin kita terbelenggu dalam kepentingan dan kepedulian sendiri, tak ada lagi ruang bagi sesama, tak ada tempat bagi si miskin papa. Suara Allah tak lagi didengar, suka-cita kasih-Nya tak lagi dirasakan, dan keinginan untuk berbuat baik pun menghilang. Ini merupakan bahaya yang sangat nyata bagi kaum beriman juga. Banyak orang menjadi korban, dan berakhir dengan rasa benci, marah dan lesu. Itu bukan jalan hidup yang dipenuhi martabat; ini juga bukan kehendak Allah bagi kita, juga bukan hidup dalam Roh yang bersumber pada hati Kristus yang bangkit (Evangelii Gaudium art. 2).

\subsection{St. Vinsensius de Paul}

Manusia memiliki dimensi spiritual. Dimensi spiritual dari manusia menggambarkan kemampuan yang dimiliki oleh manusia yang membuatnya mampu bertransendensi atau berupaya untuk melampaui dirinya; melampaui batas dari kecenderungan untuk mengasingkan diri (self-isolation), kecenderungan sibuk dengan diri sendiri (self-occupation), dan tersedot pada diri sendiri (selfabsorvation). Transendensi diri ini dilakukan dengan mencari pengetahuan, kebebasan dan cinta. Spirit manusialah yang ditarik dan bergerak menuju misteri yang tidak dapat diukur, yang oleh orang beriman disebut Allah (Downey 1997:33).

Beberapa kisah dari pengalaman St. Vinsensius dapat memperlihatkan hal ini. Siapa St. Vinsensius? St. Vinsensius lahir dalam sebuah keluarga petani kecil di desa Pouy, dekat kota Dax (Perancis Selatan) pada tahun 1581.

Mezzadri mengisahkan, orang tua Vinsensius, Jean de Paul dan Bertrande de Moras, berpikir agaknya Vinsensius cocok untuk menjadi imam. Pemikiran itu 
muncul bukan karena dia lebih baik atau lebih religius dari saudara-saudaranya. Untuk sementara, hal itu bukan soal iman atau panggilan melainkan lebih pada soal pekerjaan dan masa depan keluarga. Bila kelak Vinsensius menjadi imam, dia akan memberikan jaminan hidup yang sejahtera untuk seluruh keluarganya. Bagi orangtuanya, yang tinggal di desa, di wilayah Perancis Selatan, pemikiran seperti itu alami.

Vinsensius adalah figur yang benar-benar berupaya meraih impian untuk ditahbiskan menjadi imam. Ayahnya meninggal dunia pada masa studinya di universitas. Sejak peristiwa itu, dia tak mau merepotkan keluarganya. Dia mencari biaya hidup dan uang kuliahnya sendiri, dengan menjadi tutor di sebuah asrama. Dia menjalani dan mengurus sendiri tahap-tahap yang harus dia penuhi menuju tahbisan imam. Bahkan untuk menghubungi uskup yang akan mentahbiskannyapun, dia urus sendiri. Dengan modal pendidikan teologi di Universitas Toulouse dia berharap akan memperoleh jabatan yang terhormat dalam Gereja dan sekaligus mendatangkan income yang baik melalui jabatan tersebut. Keinginannya untuk memenuhi harapan keluarga, menopang mereka secara finansial, terungkap dalam surat yang ditulisnya kepada ibunya. Isi surat itu adalah hingga sampai saat dia menulis surat tersebut, dia belum dapat menolong sebagaimana mestinya dan akan berupaya agar keadaannya menjadi lebih baik (1992: 9-13).

Paling tidak ada tiga peristiwa yang memberikan pengaruh kuat atas cara hidup Vinsensius. Ke tiga peristiwa itu adalah pengalaman biasa yang terjadi dalam hidup sehari-hari, bukan pengalaman yang spektakuler. Kita akan melihat ke tiga peristiwa itu satu demi satu.

\subsubsection{Dituduh sebagai Pencuri}

Vinsensius pernah tinggal satu rumah dengan seseorang yang berasal dari wilayah yang sama dengan Vinsensius sendiri. Suatu hari ketika Vinsensius sakit dan harus berbaring ditempat tidur, seseorang datang untuk mengantar obat untuknya. Pada saat hendak meninggalkan ruangan itu, orang tersebut melihat dompet terletak pada salah satu tempat di ruangan itu dan lalu mengambil dompet itu. Vinsensius tidak tahu hal itu. Dia baru menyadari peristiwa itu ketika teman serumahnya, pemilik dompet itu meminta penjelasan dari Vinsensius tentang dompetnya yang telah hilang. Vinsensius tidak dapat memberikan penjelasan yang meyakinkan teman serumahnya bahwa bukan dia yang mengambil uang tersebut. Karena itu Vinsensius dituduh sebagai seorang pencuri. Tuduhan itu sangat memalukan baginya karena pada saat itu dia sangat ambisius untuk memperoleh jabatan yang sangat terhormat dalam Gereja, dan karena itu berupaya menarik perhatian orang-orang penting dalam lingkungan Gereja. Dengan peristiwa itu 
nama baiknya hilang. Tetapi Vinsensius memutuskan untuk diam, tidak membela dirinya. Dikemudian hari, dia mendeskripsikan peristiwa ini sebagai berikut:

Ada seseorang dalam kongregasi, ketika dituduh telah merampok temannya, dan ketika tuduhan itu disebar luaskan, dia memilih untuk tidak membela dirinya, dia merenung dan melihat dirinya dituduh. Apakah kamu menolak tuduhan itu? Kamu dinyatakan melakukan sesuatu yang tidak kamu lakukan. Oh, tidak!, serunya, berpalinglah kepada Allah, saya harus menerima hal itu dengan sabar. Dan itulah yang dia lakukan (XI 337) (Mezzadri 1992: 9-10).

Peristiwa yang memalukan ini berubah karena akhirnya pencuri itu ditemukan. Tetapi pada waktu itu, Vinsensius telah merasakan kesedihan orang yang tidak mempunyai suara dan tidak mempunyai pembela. Dalam peristiwa dia menentukan sikap, tidak reaktif melainkan responsif. Dia memilih untuk bersabar dan diam seribu bahasa, tidak membela diri tapi berpaling kepada Allah.

\subsubsection{Folleville}

Roman mengisahkan, suatu kali Januari 1617 di Folleville, seorang yang sedang sakit parah ingin bertemu dengan Vinsensius. Madame de Gondi dan Vinsensius pergi ke rumah orang tersebut. Di dalam rumah sederhana orang yang sakit parah itu, Vinsensius duduk dekat dengannya untuk mendengar pengakuan dosanya. Vinsensius mendorong agar orang sakit tersebut melakukan pengakuan umum, semua dosa dalam hidupnya. Orang itupun mulai menuturkan semua dosadosanya yang menyedihkan. Lebih buruk dari yang diduga oleh Vinsensius. Orang sakit itu adalah orang baik dan terpandang di desa itu, tak pernah memperlihatkan bahwa hati nuraninya terbebani oleh dosa berat. Dari tahun ke tahun, dari pengakuan dosa yang satu ke pengakuan dosa yang lain, dia diam karena ketidaktahuan atau karena malu atas dosa berat yang telah dia lakukan. Dalam rahmat pengakuan dosa itu, Vinsensius menarik dan membebaskan jiwanya dari kungkungan si jahat. Untuk beberapa saat, dia sangat menyesal, merasa amat bersalah atas dosa-dosanya tetapi kemudian terbebas dan bersyukur. Hatinya dipenuhi dengan kegembiraan yang amat besar.

Dia mengumpulkan keluarga dan tetangga ke rumahnya. Dia menceritakan pengalamannya. Secara terbuka dia mengungkapkan kesalahan-kesalahan yang telah dia lakukan, sementara sebelumnya bahkan secara rahasiapun di kamar pengakuan dosa dia tidak berani mengakuinya. Dia lega dan bersyukur kepada Tuhan yang telah membebaskannya melalui pengakuan dosa tersebut. Tiga hari kemudian dia meninggal dengan damai.

Madame de Gondi yang menyaksikan semua peristiwa ini gemetar dan merasa ngeri. Bagi de Gondi, hal yang dialami oleh yang mengaku dosa itu pasti 
terjadi pada orang-orang di wilayah itu. Katanya "kalau orang baik seperti dia, tampak baik tetapi ternyata berperilaku sangat buruk, apa lagi orang-orang yang memang hidupnya tidak baik. Tentulah banyak jiwa-jiwa yang tidak selamat atau masuk ke neraka. Apa yang harus dilakukan?”.

Minggu berikutnya, atas kesepakatan Madame de Gondi dan Vinsensius pengakuan dosa diadakan di Gereja. Vinsensius memilih agar hal itu dilangsungkan pada tanggal 25 Januari, pesta bertobatnya St. Paulus. Di dalam gedung Gereja itu, Vinsensius melihat banyak orang-orang sederhana berkumpul, suatu hal yang biasa di desa-desa di Perancis. Mirip dengan orang-orang sederhana di kampung halamannya di Pouy, pekerja kasar maka tingkahnya juga cenderung kasar. Dia melihat tipe kaum perempuan yang juga sama yakni ignorant dan saleh. Dia melihat orang-orang muda dan anak-anak yang tak berdosa. Vinsensius tidak memiliki apapun untuk diberikan kepada orang-orang miskin itu selain iba terhadap mereka. Dia menyampaikan kata-kata yang penuh pengertian dan kebaikan yang intens terhadap sesamanya yang tersisih itu.

Kotbahnya kena di hati umat. Dia menuntun, menggerakkan hati mereka dan mendorong mereka untuk mengaku dosa. Banyak dari orang-orang miskin itu menanti giliran untuk mengaku dosa sampai mereka harus minta tolong kepada beberapa romo yang ada di wilayah itu untuk menolong. Vinsensius melakukan hal yang sama di beberapa desa, hasilnya selalu sama. Banyak umat yang tergerak hatinya untuk mengaku dosa. "Allah berkenan memberkati kata-kata saya”, demikian kata Vinsensius. Ia juga mengatakan bahwa keberhasilannya disebabkan oleh iman dan keyakinan Madame de Gondi terhadap Vinsensius.

Pengalaman ini mempunyai efek yang menentukan bagi Vinsensius karena baginya peristiwa 25 Januari, pesta bertobatnya St. Paulus adalah penyataan rencana Allah atas dirinya. Dari peristiwa itu dia memahami bahwa dia dipanggil untuk mewartakan Injil kepada orang-orang miskin di desa (2002: 114-115).

\subsubsection{Francis de Sales}

Roman menuliskan, 1618 Vinsensius berjumpa dengan Francis de Sales, seorang uskup, dalam salah satu pertemuan. Pertemuan yang tak direncanakan oleh Vinsensius, hanya ikut serta saja dalam event itu. Akan tetapi pertemuan itu sangat berkesan bagi Vinsensius, hingga efek dari pertemuan tersebut lestari dalam dirinya sampai akhir hidupnya. Perjumpaan itu bukan sekedar beramahtamah sebagaimana biasa terjadi dalam sebuah pertemuan melainkan momen perjumpaan personal. Terbuka, terinspirasi dan saling percaya. Mereka berdua menjadi teman yang akrab bagi satu sama lain.

Hal yang mengesankan bagi Vinsensius dalam perjumpaan itu adalah figur Francis de Sales, yang sungguh rendah hati. Kerendahan hati uskup itu memberikan inspirasi segar baginya. Francis de Sales menceritakan bahwa dalam 
salah satu kotbah, dengan sengaja dia berkotbah dengan cara yang amat sederhana di hadapan orang-orang terkemuka yang semuanya berasal dari lingkungan kaum bangsawan. Francis sadar bahwa pendengarnya menantikan khotbah yang membuat mereka terpukau, terkesima dengan bahasa yang indah selaras dengan status mereka sebagai bangsawan. Francis memang piawai berkhotbah. Tetapi saat itu Francis hanya menceritakan kisah St. Martinus yang memotong mantelnya pada musim dingin dan memberikannya kepada seorang miskin yang kedinginan. Kisah itu saja. Hal yang dilakukan oleh Francis itu adalah tindakan yang heroik. Francis menginginkan hal biasa saja, jauh dari sikap pamer.

Latar belakang mereka berdua sangat kontras. Dari status sebagai anak bangsawan dan pendidikan, Francis masuk ke dalam kalangan yang paling tinggi dan dari status sosial, ia sangat disegani. Sementara Vinsensius berasal dari keluarga petani sederhana dan berperan sebagai kapelan dalam keluarga de Gondi, sebuah posisi yang tak jauh beda dengan para pelayan lainnya di istana de Gondi. Francis berada pada level tertinggi dalam lingkup hirarki Gereja, bukan hanya karena jabatannya, tetapi juga karena pengakuan publik atas kesuciannya. Vinsensius adalah orang yang baru saja menemukan arah panggilan imamatnya melalui salah satu pengalamanya di Folleville dan tidak mempunyai jabatan apapun dalam Gereja. Figur Francis sangat mengesan baginya karena dalam diri orang itu dia menemukan kesucian. Hal itu menarik baginya. Figur Francis yang demikian itu menggerakkan hatinya dan berkomitmen, lahir dan batin, untuk mengikuti jejak Francis.

Kekaguman Vinsensius terhadap Francis dan persahabatan mereka yang akrab yang lahir dari perjumpaan personal tidak pernah hilang, juga setelah Francis meninggal dunia. Buku yang ditulis oleh Francis de Sales Treatise on the Love of God and the Introduction to the Devout Life menjadi buku bacaan rohani yang sangat diminati dan mempengaruhi pola hidup Vinsensius. Kelak dia menganjurkan agar buku itu dibaca oleh para romo CM dan suster Puteri Kasih karena merupakan kesaksian cinta yang sangat bersemangat kepada Allah. Bahkan rencana Vinsensius untuk mendirikan komunitas religius yang sama sekali baru pada masa itu, religius perempuan yang berkarya di kalangan umat, mendapatkan dukungan doktrin teologi dari buku tersebut. Di dalam buku itu dia melihat dan menemukan jalan yang sederhana menuju kesucian (2002: 149-153).

Dalam ke tiga peristiwa ini tampak dimensi spiritual Vinsensius, kemampuan yang dimiliki olehnya, yang membuatnya mampu bertransendensi atau berupaya untuk melampaui dirinya; melampau kecenderungan sibuk dengan diri (self-occupation) atau tersedot pada diri sendiri (self-absorvation)atau kecenderungan untuk mengasingkan diri (self-isolation). Transendensi diri ini dia lakukan dengan mencari pengetahuan, kebebasan dan cinta. Spirit manusialah 
yang ditarik dan bergerak menuju misteri yang tidak dapat diukur, yang oleh orang beriman disebut Allah.

Dari perspektif pemahaman tentang Allah sebagai Penyelenggaraan Ilahi, pengalaman St. Vinsensius dapat dimengerti secara baru dalam terang pendapat Doherty. Doherty mengatakan, Allah sebagai Penyelenggaraan Ilahi membawa gerakan keberadaan manusia kepada suatu makna atau arti. Gerakan keberadaan itu ditandai oleh pengalaman kehilangan akan hal tertentu tetapi serentak memperoleh hal baru, merasa kacau tetapi kemudian tertata. Pengalaman seperti itu mengijinkan perubahan pada gerakan keberadaan manusia kepada kualitas yang lebih baik. Hal itu terjadi karena Penyelenggara Ilahi membukakan makna atau arti yang baru kepada seseorang dan dengan demikian orang tersebut melihat dan memperoleh makna tersebut. Pengalaman memperoleh makna itu signifikan, sebab dalam dan melalui pengalaman itulah Allah mengijinkan manusia mengalami kebaikan-Nya, perlindungan-Nya, kasih-Nya dalam pengalaman pahit yang terjadi dalam hidup seseorang (1993: 790-792).

Penyelenggara Ilahi membawa dan membukakan makna tertentu. Dinamika seperti ini terjadi pada Vinsensius. Gerakan keberadaannya ditandai oleh kehilangan cita-cita yang melihat imamat sebagai karir dan sekaligus memperoleh makna yang baru atas imamatnya, mengalami kekacauan atas hidupnya tetapi kemudian tertata kembali, tak teratur menjadi teratur; pengalaman ini mengijinkan perubahan hidup yang lebih berkualitas. Dari penyataan diri Allah yang terjadi dalam pengalaman sehari-hari, bukan dari peristiwa yang spektakuler, Vinsensius memperoleh makna dan perspektif baru dalam hidupnya yakni pembawa Injil kepada orang-orang miskin.

\subsection{Dimensi Spiritual}

Seperti yang sudah tertulis pada bagian awal, bahwa manusia memiliki dimensi spirit. Sebagaimana dikatakan oleh Downey, kata spirit dipakai untuk menamakan dimensi yang istimewa dari manusia tetapi tidak berlawanan dengan materi, yakni badan. Individu dimengerti sebagai satu kesatuan, satu keseluruhan yang utuh, dari pada sebuah kombinasi dari dua bagian yang bersaing, yaitu badan dan jiwa, daging dan roh, pikiran dan masalah. Dimensi roh dari manusia menggambarkan kemampuan yang dimiliki oleh manusia yang membuatnya mampu bertransendensi atau bertumbuh dengan melampaui kecenderungan negatif yang ada pada dirinya. Dalam dirinya, manusia secara alami adalah memiliki dimensi spiritual, sebagaimana telah tampak dalam diri St. Vinsensius.

Hidup manusia dan aktifitasnya, event dan sejarah dapat membukakan kehadiran dan tindakan Allah dan itu adalah rahmat Allah. Semua hal ini dapat menyampaikan kehidupan Allah yang sesungguhnya, yang secara alamiah sifatnya adalah mengekspressikan dan menyampaikan cinta dalam dan melalui 
ciptaan, dan di atas segalanya melalui manusia. Dalam pandangan ini, spiritualitas berakar dalam hidup sehari-hari, dari pada dalam hal-hal yang jarang terjadi atau peristiwa yang sangat luar biasa. Hal-hal yang biasa, yang membosankan, siang dan malam adalah kesempatan menjumpai misteri rahmat yang tidak dapat diukur. Rahmat, penyataan komunikasi pribadi Allah, masuk dengan leluasa di dalam dunia.

Hal terpenting disini adalah keyakinan bahwa ada kecocokan antara sifat alami manusia dengan rahmat Allah. Transformasi yang dibawa oleh hidup Allah menghasilkan kesempurnaan terhadap sifat alami manusia walaupun dinodai oleh dosa, secara fundamental tetap baik karena dicipta seturut gambar Allah. Selangkah lebih jauh, semua ciptaan, manusia dan yang bukan manusia, dapat menjadi tempat untuk melakukan discerment tentang penyataan kehadiran Allah, untuk transformasi hidup manusia dan dunia karena rahmat Allah.

Hal ini tentu saja bukan untuk mengatakan bahwa Allah dan manusia adalah sama. Juga tidak mengimplikasikan bahwa manusia dan aktifitasnya adalah ilahi, atau bahwa manusia menjadi Allah di dalam proses transformasi dan dalam rahmat Allah. Bukan demikian. Dalam mengenali hubungan dan persamaan dalam hal relasi yang terjalin antara Allah dan dunia, harus diterima apapun kemiripan yang mungkin, tetapi ketidakmiripan dan discontinuitas tetap.

Dalam diri setiap orang ada keinginan untuk berada dalam relasi dengan Allah. Mungkin keinginan ini eksplisit, seperti halnya dalam diri orang beriman, yang menamakan rahasia rahmat yang tidak dapat diukur itu, Allah. Atau mungkin implisit, sebagai mana terjadi pada kalangan orang yang tidak beragama dan atheis. Dicipta, sementara, terbatas, dan rindu pada kepenuhan, manusia mencari yang tidak dicipta, abadi, tidak terbatas dan sangat luas. Integrasi antara tubuh, pikiran, dan jiwa perlahan terjadi dalam pencarian pengetahun, kebebasan dan cinta yang mempunyai asal dan akhir dalam yang suci, sebuah kekuatan yang tertinggi, awal yang tidak berawal, realitas yang disebut oleh orang beriman Allah. Doa dan kebiasaan lainnya yang berhubungan dengan hidup rohani dimengerti dengan baik ketika dilihat dalam terang pengertian ini, umum, dan keinginan universal untuk berada dalam relasi dengan Allah (1997: 30-35).

\section{Kesimpulan}

Paus Fransiskus dalam Evangelii Gaudium, memperlihatkan bahaya besar dalam dunia sekarang ini, yang diliputi konsumerisme yakni kesedihan dan kecemasan yang lahir dari hati yang puas diri namum tamak, pengejaran akan kesenangan secara sembrono dan hati nurani yang tumpul. Manusia terbelenggu dalam kepentingan dan kepedulian sendiri sehingga tak ada lagi ruang bagi sesama juga bagi Allah. Dalam kondisi manusia yang demikian, saat ini muncul 
masalah baru. Seluruh umat manusia, termasuk bangsa kita mau tak mau harus mengadopsi pola hidup yang baru karena virus corona.

Baik sebelum virus corona terjadi maupun dalam pandemi ini, relevan untuk memahami dengan baik dimensi spiritual manusia. Sebuah dimensi fundamental yang dimiliki oleh manusia, suatu hal yang membuatnya mampu bertransendensi atau berupaya untuk melampaui dirinya, melampaui batas dari kecenderungan negatif yang dimilikinya demi kehidupan yang lebih baik. Sadar bahwa dimensi spiritual itulah yang terus-menerus menggerakkan individu kepada hidup yang lebih bermartabat dan baik.

\section{DAFTAR PUSTAKA}

Boff, Leonardo.,1995, Ecologi and Liberation: a New Paradigm. Maryknoll, Ny: Orbis.

Byrne, Lavinia ed., 1991, The Hidden Tradition: Women's Spiritual Writings Rediscovered: An Anthology. New York: Crossroad.

Conn, Joan Wolski., 1996, Women's Spirituality: Resources for Christian Development. Mahwah, NJ: Paulist.

Doherty,Barbara S.P., 1993, Providence, The new Dictionary of Catholic Spirituality, Minnesota: The Liturgical Press.

Downey, Michael., 1997,Understanding Christian Spirituality. Mahwah, NJ: Paulist.

Mezzadri,Luigi., 1992, A short Life of St. Vincent de Paul. Dublin: The Columbia Press.

Roman,Jose Maria., 2002,St. Vincent de Paul Biography, London: Melisende.

Xavier,Joseph., 2014, Rahner's 'Anthropological Turn' in Theology And Doctrine of Revelation, Asian HorizonsPages: 357-377, Vol. 8, No. 2, June.

Paus Fransiskus., 2013, Evangelii Gaudium. 